\title{
The Role of Vocabulary vs. Syntactic Knowledge in L2 Reading Comprehension
}

\author{
Zafer Susoy a * (D), Seray Tanyer a† (iD) \\ a Anadolu University, Yeşiltepe Mh. Yunus Emre Kampüsü Tepebaşı, Eskişehir, 26470, Turkey
}

\begin{tabular}{l|l|l} 
Received 01 June 2018 & Received in revised form 26 July 2018 & Accepted 12 October 2018
\end{tabular}

\section{APA Citation:}

Susoy, Z., \& Tanyer, S. (2019). The role of vocabulary vs. syntactic knowledge in L2 reading comprehension. Eurasian Journal of Applied Linguistics, 5(1), 113-130. Doi: 10.32601/ejal.543787

\begin{abstract}
Research in literature reports the importance of L2 vocabulary and syntactic knowledge on the learners' reading comprehension. In this regard, the current study investigated the role of vocabulary knowledge that is disunited into depth and breadth dimensions and syntactic knowledge in the reading comprehension scores of an advanced cohort of English as a Foreign Language (EFL) learners. In particular, this study examined the relationship of vocabulary knowledge (with its two dimensions) and syntactic knowledge with reading comprehension scores of 30 Turkish EFL learners and the extent to which these knowledge types explain the variance in reading comprehension scores. Measures of vocabulary breadth, vocabulary depth, syntactic knowledge and reading comprehension were used. The data analysis procedure included the descriptive statistics, Pearson product-moment correlations and multiple regression analysis. The results showed that the depth of vocabulary knowledge predicts the L2 reading comprehension the best when the effect of vocabulary size and syntactic knowledge is controlled. These findings are discussed at the end of the study with future research suggestions and limitations.
\end{abstract}

(C) 2019 EJAL \& the Authors. Published by Eurasian Journal of Applied Linguistics (EJAL). This is an open-access article distributed under the terms and conditions of the Creative Commons Attribution license (CC BY-NC-ND) (http://creativecommons.org/licenses/by-nc-nd/4.0/).

Keywords: Vocabulary knowledge; syntactic knowledge; vocabulary breadth; vocabulary depth; EFL reading comprehension

\section{Introduction}

\subsection{The scope}

Reading, in basic terms, was defined as "dealing with language messages in written or printed form” (Urguhart \& Weir, 2014, p.14). Fundamentally, this definition seems to go for both reading in one's native language and in a foreign or second language (L2). Grabe (2009), however, asserted that being a proficient reader in the contemporary societies of today, in most cases, is equivalent to reading in an L2 (English is referred here) since the number of students who are expected to learn English is measured with millions. Grabe (2009) went on mentioning the reasons why so many individuals are supposed to be competent at reading in English;

\footnotetext{
* Corresponding author. Tel.: +90-505-925-0623

E-mail address: zsusoy@anadolu.edu.tr / zafersusoy@gmail.com

† $\underline{\text { seraytanyer@gmail.com }}$
} 
- The high English proficiency levels required by academic objectives can be achieved whereby adept reading skills.

- It creates better opportunities of job, communication, travel and educational advancement.

- It allows the individuals to be more knowledgeable about other cultures and provides access to refined studies for career improvement.

Therefore, it is understood that achievement in L2 reading comprehension is of great significance for the learners (Chen, 2009). Likewise, the question of what predicts L2 reading comprehension has become a matter to be discovered and been researched from a wide range of perspectives. To be more specific, the relationships between metacognitive strategies and L2 reading (e.g., Boulware-Gooden, Carreker, Thornhill, \& Joshi, 2007; Schoonen, Hulstjiin, \& Bossers, 1998), between topic familiarity and L2 reading (e.g., Lee, 2007; Peretz \& Shoham, 1990), between some affective factors, language proficiency, gender and L2 reading (e.g., Brantmeier, 2003; Cutting \& Scarborough, 2006; Sellers, 2000; Wigfield \& Guthrie, 1997) have been thoroughly studied. In addition to these factors, vocabulary and syntactic knowledge have also been claimed to play some roles in reading comprehension (Grabe, 2009; Laufer, 1997), which makes the attempt to examine these roles a valuable one.

\subsection{Literature review and aim}

There are a number of research studies in the literature reporting the importance of L2 vocabulary knowledge on the learners' reading comprehension. Research suggests that vocabulary knowledge plays a major role in the achievement of good language skills and language competence (Laufer, Elder, Hill, \& Congdon, 2004).

Laufer (1997) asserted that understanding the given vocabulary in any text is the strongest prerequisite for text comprehension. Verhoeven (2000) reached a positive and moderately strong relationship between L2 reading comprehension and vocabulary knowledge in young learners $(r=.63)$ and advised that reading instruction should take the learners' vocabulary knowledge into serious consideration. Likewise, with young Dutch learners of English again, Schoonen, Hulstijn, and Bossers (1998) reported a higher positive correlation $(r=.76)$ between vocabulary knowledge and reading abilities. As understood, these two researches did not differentiate between the proposed traits of vocabulary knowledge. However, vocabulary knowledge, to be specified, is designated to be a multifaceted construct (Boulware-Gooden, Carreker \& Thornhill \& Joshi, 2007, Cutting \& Scarborough, 2006; Schoonen, Hulstjiin, \& Bossers, 1998; Wigfield \& Guthrie, 1997). Two of the most significant traits in the vocabulary knowledge that have been widely discussed in the literature are described as the breadth and depth dimensions of vocabulary knowledge (Kaivanpanah \& Zandi, 2009; Shiotsu \& Weir, 2007; Zhang, 2012).

Breadth dimension of the vocabulary knowledge, in simple terms, is characterized with regard to the sheer number of the words known by the learners (breadth), while 
the depth dimension is related to the quality of this knowledge. Vocabulary depth, that is to say, is concerned with the extent to which learners;

- know with what words the known words mostly correlate,

- have an expertise on the different semantic properties of the words (Qian, 1999).

The assumption surrounding the breadth of vocabulary is that in order for the learners to soundly comprehend a text, they need almost 5.000 words (Laufer, 1997), and some researchers took it even a step further by concluding that foreign language learners need as many words as they do in their first languages (L1) (Goulder, Nation, \& Read, 1990). As for numbers forming the breadth of the vocabulary knowledge, another suggestion came from Nation (2006). He asserted that foreign language learners are in need of "8.000 to 9.000 word family vocabulary" "for unassisted comprehension" of a text (p. 59). In comparison with depth trait of vocabulary knowledge (as well as syntactic knowledge), breadth of vocabulary was found to be one of the biggest contributory constructs to the L2 reading comprehension (Chen, 2009). The depth of vocabulary, as mentioned earlier, is regarded as possessing a broader scope of knowledge including the ability to distinguish the different semantic and morphological features of a single known word and identify and use it in different contexts appropriately (Qian, 1999). According to Qian (1999, p. 284), the depth trait of vocabulary knowledge entails the knowledge of "pronunciation, syntactic and morphological properties, meaning, frequency and register" (p. 284). Qian (1999; 2002) highlighted the exclusive contribution of depth of vocabulary knowledge to the L2 reading comprehension when the effect of breadth of vocabulary was controlled, thus asserting the relatively more notable effect of the depth aspect of the vocabulary knowledge.

Apart from the effect of vocabulary, the literature also discusses the importance of the syntactic knowledge in L2 reading comprehension. Grabe (2009) wrote that "time, certainty, location, identifiability, event relations and noun linkages" (p. 203) are among the merits offered by the syntactic knowledge to be exploited in the L2 reading comprehension. Shioutsu and Weird (2007) conducted three successive studies with tertiary level Japanese learners of English both in England and in Japan. The findings of all three studies revealed that the syntactic knowledge provided relatively better predictive insights into the reading comprehension of learners as compared with vocabulary knowledge. Similarly, in Iran, Kaivanpanah and Zandi (2009) studied the correlations between syntactic knowledge, vocabulary knowledge and L2 reading achievement of a group of 57 EFL learners. Their findings uncovered that syntactic knowledge contributed significantly more to the reading comprehension than vocabulary knowledge did. Although Kaivanpanah and Zandi's study (2009) acknowledges the significance of depth of vocabulary knowledge, it also emphasizes the correlation between syntactic knowledge and collocation knowledge. In contrast, Zhang (2012) more recently carried out a study with 190 proficient Chinese learners of English. After having measured the learners' vocabulary and syntactic knowledge and the reading comprehension rates, he concluded that the syntactic knowledge did 
not predict the reading comprehension as much as the vocabulary knowledge. Additionally, Zhang (2012) also found that the vocabulary knowledge alone, with the syntactic knowledge being statistically controlled, contributed significantly to the reading comprehension; however, the same was not applicable for the syntactic knowledge.

As understood, the hierarchy in the nature of these correlations in terms of predictive power is complex. Although both vocabulary and syntactic knowledge are acknowledged to have a part in L2 comprehension, the predictive powers of these two variables vary. In a study, for example, Bossers (1992) ended up with only an insignificant difference between vocabulary and syntactic knowledge in terms of their predictive capacity of L2 reading. On the other hand, Yamashita (1999), in a large scale study, concluded that vocabulary predicted L2 reading comprehension much better than syntactic knowledge. In contrast, Van Gelderen, Schoonen, de Glopper, Hulstijn, Simis, Snellings and Stevenson (2004) found that syntactic knowledge is associated with reading comprehension more than with vocabulary knowledge. Although we have so far presented a part of literature reporting the inter-correlations between vocabulary knowledge, syntactic knowledge, and L2 reading comprehension, it seems that the findings do not unite in a certain point; instead they diversify. Thus, in the light of the literature reviewed, the present study aims to examine whether there is an effect of vocabulary knowledge (e.g. breadth and depth) and syntactic knowledge on L2 reading comprehension of a cohort of Turkish advanced learners of English. The present study is governed by the following research questions to achieve the purposes;

1. How well do vocabulary knowledge (i.e. breadth and depth) and syntactic knowledge predict $\mathrm{L} 2$ reading comprehension?

2. Which one predicts L2 reading comprehension better: vocabulary or syntactic knowledge?

\section{Method}

\subsection{Participant characteristics}

The participants of the present study were 30 university students majoring at the English Language Teaching (ELT) Department of a Turkish public university. All the participants speak English as a foreign language, having Turkish as the native tongue. The participants are supposed to have relatively high language proficiency since the university mandated a language proficiency examination upon their entrance. The students were expected to either pass this examination or complete a one-year comprehensive language preparatory program before starting to follow the ELT degree program. The participants were selected through the convenience sampling method in which the greatest consideration is the ease of access to the participants (Creswell, 2012). 


\subsection{Instruments}

Data for this study were collected by means of four different tests:

- a standardized English reading comprehension test,

- a vocabulary breadth (size) test,

- a vocabulary depth test and 4) a test of syntactic knowledge.

\subsubsection{Reading comprehension test}

The reading comprehension test (RCT henceforth) was selected from a TOEFL IBT training book (i.e., McGraw, 2009; p. 69-78). The reading passage handles its subject from various points of views. It requires the learners to distinguish between facts and details and between important and minor ideas as well as to infer about the implied information. Due to time limitation, only one reading passage that had 13 comprehension questions was decided to be given. The comprehension questions had been provided in three formats; a) 11 multiple choice questions with only one correct option out of $4, \mathrm{~b}$ ) a question that requires the learners to 'insert a sentence' (McGraw, 2009 , p. 9) where it fits the best and, c) a question with more than one possible correct option (see Appendix A). Each correct answer corresponds to 1 point in the test. Therefore, the maximum score that can be gained from the test is 13 .

\subsubsection{Vocabulary breadth (size) test}

The vocabulary size test (VST henceforth), utilized in this study, was the revised version (Schmitt, Schmitt, \& Clapham, 2001) of an earlier test of vocabulary. Schmitt et al. (2001) found a reliability over point of .90 for each word family level. Qian (1999) reported a reliability at the point of .92 for the test. The VST is comprised of five-word family levels; a) 2000 and 3000-word family levels which include the highly frequent words, b) 5000-word family level which includes words falling into a frequency between low and high, and c) 10000-word family list which includes low frequent words, and d) the academic word list which consists of the specific words that are commonly needed for the academic studies. As seen in Figure 1, each of the five-word family level has 10 items with 6 words to be correctly placed onto the definition slots given at the right side. An example VST item is as follows (see Appendix B). Each correct matching in fifty slots makes 1 point and the possible highest score in VST is 150 points.

\begin{tabular}{ll}
\hline 1 business & part of a house \\
2 clock & animal with four legs \\
3 horse & something used for writing \\
4 pencil & \\
5 shoe & \\
6 wall & \\
\hline
\end{tabular}

Figure 1. An example matching slot from the VST (Schmitt et al., 2001) 


\subsubsection{Vocabulary depth test}

The Word Associates Test, aimed to assess the depth dimension of vocabulary knowledge (Vocabulary Depth Test; VDT henceforth), was originally developed by Read (1993). The test then was refined and revised by Read (2000). This revised version was utilized in the present study which consisted of 40 items with an adjective given at the first place and 8 following words, four of which are somehow related to the given adjective. The learners were expected to circle these four semantically related words and given 1 point for each correct circling. Therefore, the highest possible score at the test was 160 . The four related words are present both in the right and in the left box. However, the number of the related words in each box is variant each time to reduce the chance of guessing. An example item from the test is: (see: http://www.lextutor.ca/tests/associates/).

\begin{tabular}{l}
\hline sudden \\
\hline$\square$ beautiful $\square$ quick $\square$ surprising $\square$ thirsty \\
\hline
\end{tabular}

Figure 2. An example slot from the VDT (Read, 2000).

\subsubsection{Test of syntactic knowledge}

The structure and written expression part of a TOEFL practice test, found on the web, was utilized for this study as a measure of syntactic knowledge (http://alvand.basu.ac.ir/ amozesh/English\%20Language/ETS\%20TOEFL\%20Prepara tion\%20kit\%20Volume\%202\%20(reading\%20and\%20structure).pdf/Practice\%20Struct ure\%20H.pdf). The test had 15 grammar questions in the multiple-choice format with four options and 25 sentences with four underlined phrases one of which was erroneous. The learners were expected to find and circle the error in the given sentences. Each correct option corresponds to 1 point and the possible highest score that can be achieved is 40 .

\subsection{Data collection and analysis procedure}

Data collection lasted for two weeks, the participants were first given the vocabulary breadth and depth tests and the following week they were given the reading comprehension and syntactic knowledge tests. The data collection procedure was carried on during the regular class hours and the participants were informed of the volunteer participation. Those who didn't take the tests given in the $2^{\text {nd }}$ week were excluded from the study.

The data analysis procedure included the descriptive statistics, correlations and multiple regression analyses. The descriptive analysis revealed the mean scores, standard deviations, maximum and minimum scores achieved in each test. Pearson correlations were computed to explore the relationships between the variables and additionally, a regression analysis was conducted to find out the unique contribution of each independent variable (i.e., vocabulary knowledge and syntactic knowledge) to the dependent variable of the study (i.e., L2 reading comprehension). The statistical analysis was conducted on the Statistical Software Package, SPSS 20. 


\section{Results}

As the first step, a test of normality on the variables were conducted. As suggested in the literature (Demir, Saatçioğlu, \& İmrol, 2016; p. 134), if the sample size is less than 35, the Shapiro-Wilk test (Shapiro \& Wilk, 1965) can be run. For this reason, Shapiro-Wilk test was used to assess normality in this study. Given that $p=.474$ for vocabulary breath, $p=.996$ for vocabulary depth, $p=.857$ for syntactic knowledge and $p=.121$ for reading comprehension, we concluded that the data in each four variables were normally distributed. As the assumption of normality has been met for this sample, the researchers used parametric tests for analyses.

Table 1 displays the number of participants, mean values, minimum and maximum scores achieved by the participants in four variables. It is noteworthy to remind that the maximum possible scores in each variable measure are different. While the possible highest score in vocabulary breadth test is 150 points, it is 160 in vocabulary depth test, 40 points in the syntactic knowledge test, and 13 points in the reading comprehension test.

Table 1. Descriptive Statistics

\begin{tabular}{lccccc}
\hline & $N$ & $M$ & $S D$ & MIN. & MAX. \\
\hline Vocabulary Breadth & 30 & 132,43 & 6,20 & 237 & 292 \\
Vocabulary Depth & 30 & 116.47 & 9.97 & 96 & 135 \\
Syntactic Knowledge & 30 & 31.80 & 3.74 & 24 & 38 \\
Reading Comprehension & 30 & 7.93 & 2.25 & 2 & 11 \\
\hline
\end{tabular}

To answer the research questions which seek to reveal if there is any relationship between the vocabulary knowledge measured by two different constructs (depth and breadth), syntactic knowledge, and L2 reading comprehension, a Pearson's ProductMoment correlation analysis was computed (see Table 2 below). The correlation findings uncovered a significant strong positive correlation between the depth dimension of vocabulary knowledge and L2 reading comprehension $(r=.718, p<.01)$, which means a direct relationship between the two variables pointing that those who get higher scores in the vocabulary depth test also get higher scores in the reading comprehension test. Our correlation analysis could not find strong or significant correlations between the vocabulary breadth and reading comprehension $(r=.353, p>$ $.05)$, and between the syntactic knowledge and reading comprehension $(r=.295, p>$ $.05)$.

Table 2. Intercorrelations between the variables of the study

\begin{tabular}{|c|c|c|c|c|}
\hline & $\begin{array}{l}\text { Vocabulary } \\
\text { Breadth }\end{array}$ & $\begin{array}{l}\text { Vocabulary } \\
\text { Depth }\end{array}$ & $\begin{array}{l}\text { Syntactic } \\
\text { Knowledge }\end{array}$ & $\begin{array}{l}\text { Reading } \\
\text { Comprehension }\end{array}$ \\
\hline Vocabulary Breadth & - & .426 & .218 & .353 \\
\hline Vocabulary Depth & & - & $.567 *$ & $.718^{*}$ \\
\hline Syntactic Knowledge & & & - & .295 \\
\hline Reading Comprehension & & & & - \\
\hline
\end{tabular}


Though not within the scope of this study, the correlational analysis revealed a relationship between the two independent variables of the study, namely between vocabulary depth and syntactic knowledge. As can be seen from Table 2, there is a moderately strong and significant relationship between vocabulary depth and syntactic knowledge $(r=.567, p<.05)$, meaning those who had a higher syntactic knowledge tend to have a higher vocabulary depth.

Table 3 below displays the results of the hierarchical multiple regression analysis between the dependent variable of 'reading comprehension' and three independent variables whose unique contributions in explaining the variance in the reading comprehension were examined. As can be seen in the table, the $\mathrm{R}$ square of the regression model was found to be .536 , which means that the three independent variables, altogether, explains the $53 \%$ of the variance in the reading comprehension, and this finding was found to be statistically significant $[F(3.26=4.23, p<.05]$.

Table 3. Hierarchical regression analysis (Dependent variable: Reading comprehension scores)

\begin{tabular}{lccccccc}
\hline Model & $\mathrm{R}$ & $\mathrm{R}^{2}$ & Adjusted $\mathrm{R}^{2}$ & $\mathrm{SE}$ & F Model & $\mathrm{R}^{2}$ Change & F Change \\
\hline $\begin{array}{l}\text { 1. Syntactic } \\
\text { Knowledge }\end{array}$ & .295 & .087 & .017 & 2.32 & 1.23 & .087 & 1.23 \\
$\begin{array}{l}\text { 2. Vocabulary } \\
\quad\end{array}$ & .418 & .174 & .037 & 2.20 & 1.26 & .087 & 1.27 \\
$\begin{array}{l}\text { Breadth } \\
\text { 3. Vocabulary }\end{array}$ & .732 & .536 & .409 & 1.73 & $4.23^{*}$ & .361 & $8.56^{*}$ \\
$\quad$ Depth & & & & & & & \\
\hline
\end{tabular}

${ }^{*} F$ is significant at the .05 level

When the model is further examined so as to see the unique contribution of each variable, it can be seen that 'syntactic knowledge and vocabulary breadth neither have a significant relationship with the reading comprehension nor they have any significant unique contribution to the variance in the reading comprehension. On the other hand, the third variable in the model, vocabulary depth knowledge, has a significant $\mathrm{R}$ square change value of .361, which means that controlling for the other variables, it significantly explains the $36 \%$ of the variance in L2 reading comprehension scores.

\section{Discussion}

The purpose of this study has been to investigate whether there is an effect of vocabulary knowledge (e.g. breadth and depth) and syntactic knowledge on the L2 reading comprehension of a cohort of Turkish ELT students. To do so, in our study, we computed correlational and regression analyses between vocabulary/syntactic knowledge scores and L2 reading comprehension scores obtained. As our results indicated, although the three-faceted regression model significantly explains $53 \%$ of the variance, the strongest predictor of the L2 reading comprehension was found to be the knowledge of vocabulary depth.

The Pearson correlation coefficient scores were higher than $.60(\mathrm{r}=.718, p<.01)$ merely for the vocabulary depth variable, which means that there is a positively 
strong and statistically significant relationship between vocabulary depth and L2 reading comprehension scores. This finding pointed out that a higher level of vocabulary depth knowledge is likely to lead to higher scores in an L2 reading measurement. Moreover, the hierarchical regression analysis also revealed that $36 \%$ of the total variance in the L2 reading comprehension scores, over and beyond the vocabulary breadth and syntactic knowledge, can be significantly explained by the depth dimension of vocabulary knowledge alone. However, we found only a weak and non-significant relationship between vocabulary breadth and L2 reading comprehension and it only explained less than $1 \%$ of the variance. The results of the current study, thus, provided support for the claims of divisibility of depth and size dimensions as two distinct and independent constructs within the broader zone of vocabulary knowledge (Kaivanpanah \& Zandi, 2009; Read, 2000; Shiotsu \& Weir, 2007; Zhang, 2012).

These findings regarding the effect of vocabulary on L2 reading achievement is interesting in that the inefficiency of the breadth dimension of vocabulary knowledge put forward in this study is in contradiction with previous studies considering the vocabulary breadth as the best predictor of L2 reading comprehension (e.g., Chen, 2009; Laufer, 1997; Zhang, 2012). The high predictive power of vocabulary depth, on the other hand, is in accordance with other previous research which (e.g., Qian, 1999; 2002) reported that vocabulary depth is a better predictor of L2 reading success than vocabulary breadth or syntactic knowledge. The relatively higher contribution of vocabulary depth to the L2 reading comprehension might be resulting from its more complicated nature as a construct. The depth of vocabulary, as mentioned earlier, is regarded as possessing a broader scope of knowledge including the ability to distinguish the different semantic and morphological features of a single known word and identify and use it in different contexts appropriately (Qian, 1999). According to Qian (1999), the depth trait of vocabulary knowledge entails the knowledge of "pronunciation, syntactic and morphological properties, meaning, frequency and register" (p. 284). Qian (1999; 2002) highlighted the exclusive contribution of depth of vocabulary knowledge to the L2 reading comprehension when the effect of breadth of vocabulary was controlled, thus asserting the relatively more notable effect of the depth aspect of the vocabulary knowledge. As proposed in the literature (Qian, 1999), the vocabulary depth entails knowledge of syntax and morphology. This characteristic of vocabulary depth knowledge might explain the moderate and significant positive relationship that our results reveal between syntactic knowledge scores and depth of vocabulary dimension $(r=.576, p<.05)$.

Although Shioutsu and Weir (2007) named the syntactic knowledge as "one of the deciding factors" in L2 reading comprehension, our results, in contrast, found neither any strong nor a significant relationship between the syntactic knowledge and L2 reading comprehension $(\mathrm{r}=.295, p>.05)$ nor could we provide support to the claims that syntactic knowledge explains a significant amount of variance in L2 reading comprehension (Kaivanponah \& Zandi, 2009; Van Gelderen et al., 2004). This could be because the reading comprehension in an L2 is a multi-faceted and complex zone 
where a high number of factors play a role apart from syntactic and lexical knowledge one holds in the target language. The present study focused only on the alleged contribution of lexical and syntactic knowledge to the prediction of L2 reading comprehension. However, it is well-known that a considerable amount of variance in L2 reading comprehension could be explained by either learner-related or language related elements. To be more specific, the relationships between metacognitive strategies and L2 reading (e.g., Boulware-Gooden, Carreker, Thornhill \& Joshi, 2007, Schoonen, Hulstjiin, \& Bossers, 1998) between topic familiarity and L2 reading (e.g., Lee, 2007; Peretz \& Shoham, 1990) between some affective factors: language proficiency, gender and L2 reading (e.g., Brantmeier, 2003; Cutting \& Scarborough, 2006; Sellers, 2000; Wigfield \& Guthrie, 1997) have been thoroughly studied and some links between these factors and L2 reading comprehension have been uncovered. Therefore, it should be noted that any research design which aims to explore one or two virtual factors in predicting the $\mathrm{L} 2$ reading comprehension will not be able to pose a whole picture. To do so, studies which are determined to explore as much variance as possible coming from different sources are needed to extend our understanding.

\section{Conclusions}

All in all, in this study, we presented previous research reporting the importance of vocabulary knowledge - positioning either breadth or depth dimension as more explanatory in L2 reading comprehension- and the importance of syntactic knowledge. Considering the complex nature and inter-correlations between these variables and not without limitations, our study showed that the depth of vocabulary knowledge predicts the L2 reading comprehension the best when the effect of vocabulary breadth and syntactic knowledge is controlled. We should note that the results of the current study are confined to the small number of participants. Therefore, it is best not to conclude that vocabulary breadth and syntactic knowledge is unimportant, instead, our results should be viewed as a hierarchy of variables (e.g., vocabulary and syntactic knowledge) in terms of importance and contribution to the L2 reading comprehension.

The results of the current study may reveal some helpful inferences for the EFL teachers. A clear understanding of EFL students' vocabulary knowledge may guide EFL teachers -as test developers- to develop reading tests which are more suitable to their students' competence. As Qian (1999; 2002) proposed, vocabulary depth as a vital dimension of vocabulary knowledge entails different semantic and morphological features of a single known word and identify and use it in different contexts appropriately. With this respect, EFL teachers and course book writers should consider these dimensions of vocabulary knowledge and weigh polysemy, synonymy, and collocational patterns of vocabulary items in their teaching and learning materials. The fact that vocabulary depth has shown the strongest correlation with reading comprehension as well as its significant explanation of variance shows that besides the fundamental meaning of a word, "pronunciation, syntactic and morphological properties, meaning, frequency and register" (Qian, 1999; p. 284) should not be overlooked in teaching EFL reading contexts. 
Although our study provides evidence to the notion that vocabulary is the essence of language (Zimmerman, 1997), the results should be taken with a great deal of caution as the number of our participants is limited to make wide-range generalizations related to the roles of vocabulary and syntactic knowledge on reading comprehension. The future studies should include a much greater number of participants to increase the generalizability scope. Another recommendation is concerning the administration of the vocabulary, syntax and reading comprehension measures. We gave out two measures at once in one week- breadth and depth measures and two others - reading comprehension and syntax measures - in the following week, yet, since the administration of two measures at once takes lots of time, the participants might be distracted. We already shortened the reading comprehension measure, however, if it had been longer, it could have yielded more sound comprehension results. In conclusion, the ease of administration should be assured in future research designs.

\section{References}

Barnett, M. A. (1986). Syntactic and lexical/semantic skill in foreign language reading: Importance and interaction. The Modern Language Journal, 70(4), 343-349.

Brantmeier, C. (2003). Does gender make a difference? Passage content and comprehension in second language reading. Reading in a Foreign Language, 15(1), 1-27.

Bossers, B. H. (1992). Reading in two languages: A study of reading comprehension in Dutch as a second language and in Turkish as a first language (Unpublished doctoral dissertation). Free University, Amsterdam, the Netherlands.

Boulware-Gooden, R., Carreker, S., Thornhill, A., \& Joshi, R. M. (2007). Instruction of metacognitive strategies enhances reading comprehension and vocabulary achievement of third-grade students. The Reading Teacher, 61(1), 70-77. https://doi.org/10.1598/RT.61.1.7

Chen, K. Y. (2009). An Explanatory Mixed Methods Study of EFL College Students' Vocabulary Knowledge, Syntactic Knowledge and Reading Comprehension. Retrieved from ProQuest Dissertations Publishing. (Dissertation number: 3363973; ProQuest document ID: 305149263)

Creswell, J. W. (2012). Educational research: Planning, conducting, and evaluating quantitative. Boston, MA, USA: Pearson.

Cutting, L. E., \& Scarborough, H. S. (2006). Prediction of reading comprehension: Relative contributions of word recognition, language proficiency, and other cognitive skills can depend on how comprehension is measured. Scientific Studies of Reading, 10(3), 277-299. https://doi.org/10.1207/s1532799xssr1003_5

Demir, E., Saatçioğlu, Ö., \& İmrol, F. (2016). Uluslararası dergilerde yayımlanan eğitim araştırmalarının normallik varsayımları açısından incelenmesi. Current Research in Education, 2(3), 130-148.

Grabe, W. (2009). Reading in a second language: Moving from theory to practice. New York, NY, USA: Cambridge University Press.

Goulder, R., Nation, P., \& Read, J. (1990). How large can a receptive vocabulary be? Applied Linguistics, 11(4), 341-363. https://doi.org/10.1093/applin/11.4.341

Kaivanpanah, S., \& Zandi, H. (2009). The role of depth of vocabulary knowledge in reading comprehension in EFL context. Journal of Applied Sciences, 9(4), 698-706. 
Laufer, B. (1997). The lexical plight in second language reading: words you don't know, words you think you know and words you can't guess. In J. Coady \& T. Huckin (Eds.), Second Language Vocabulary Acquisition: A Rationale for Pedagogy, (20-52), Cambridge University Press.

Laufer, B., Elder, C., Hill, K., \& Congdon, P. (2004). Size and strength: do we need both to measure vocabulary knowledge? Language Testing, 21(2), 202-226. https://doi.org/10.1191/0265532204lt277oa

Lee, S. K. (2007). Effects of textual enhancement and topic familiarity on Korean EFL students' reading comprehension and learning of passive form. Language learning, 57(1), 87-118. https://doi.org/10.1111/j.1467-9922.2007.00400.x

McGraw, H., (2009). The official guide to the TOEFL test (3rd ed.). New York, USA: Educational Testing Service.

Nation, I. (2006). How large a vocabulary is needed for reading and listening?. Canadian Modern Language Review, 63(1), 59-82. https://doi.org/10.3138/cmlr.63.1.59

Peretz, A. S., \& Shoham, M. (1990). Testing reading comprehension in LSP: Does topic familiarity affect assessed difficulty and actual performance. Reading in a Foreign Language, 7(1), 447-455.

Qian, D. D. (1999). Assessing the roles of depth and breadth of vocabulary knowledge in reading comprehension. The Canadian Modern Language Review, 56(2), 282-308. https://doi.org/10.3138/cmlr.56.2.282

Qian, D. D. (2002). Investigating the relationship between vocabulary knowledge and academic reading performance: An assessment perspective. Language Learning, 52, 513536. https://doi.org/10.1111/1467-9922.00193

Read, J. (1993). The development of a new measure of L2 vocabulary knowledge. Language Testing, 10(3), 355-371. https://doi.org/10.1177/026553229301000308

Read, J. (2000). Assessing Vocabulary. Cambridge, UK: Cambridge University Press.

Schmitt, N., Schmitt, D. \& Clapham, C. (2001). Developing and exploring the behavior of two new version of the Vocabulary Levels Test. Language Testing, 18(1), 55-88. https://doi.org/10.1177/026553220101800103

Schoonen, R., Hulstijn, J. H., \& Bossers, B. (1998). Metacognitive and language-specific knowledge in native and foreign language reading comprehension: An empirical study among Dutch students in grades 6, 8 and 10. Language Learning, 48(1), 71-106. https://doi.org/10.1111/1467-9922.00033

Sellers, V. D. (2000). Anxiety and reading comprehension in Spanish as a foreign language. Foreign Language Annals, 33(5), 512-520. https://doi.org/10.1111/j.19449720.2000.tb01995.x

Shapiro, S. S., \& Wilk, M. B. (1965). An analysis of variance test for normality (Complete samples). Biometrika, 52(3/4), 591-611.

Shiotsu, T., \& Weir, C. J. (2007). The relative significance of syntactic knowledge and vocabulary breadth in the prediction of reading comprehension test performance. Language Testing, 24(1), 99-128. https://doi.org/10.1515/cjal.2011.028

Urguhart, A. H., \& Weir, C. J. (2014). Reading in a second language: Process, product and practice. New York, NY, USA: Routledge.

Van Gelderen, A., Schoonen, R., De Glopper, K., Hulstijn, J., Simis, A., Snellings, P., \& Stevenson, M. (2004). Linguistic knowledge, processing speed, and metacognitive knowledge in first-and second-language reading comprehension: A componential 
analysis. Journal of Educational Psychology, 96(1), 19. https://doi.org/10.1037/00220663.96.1.19

Verhoeven, L. (2000). Components in early second language reading and spelling. Scientific Studies of Reading, 4(4), 313-330. https://doi.org/10.1207/s1532799xssr0404_4

Wigfield, A., \& Guthrie, J. T. (1997). Relations of children's motivation for reading to the amount and breadth or their reading. Journal of Educational Psychology, 89(3), 420-432. https://doi.org/10.1037//0022-0663.89.3.420

Zhang, D. (2012). Vocabulary and grammar knowledge in second language reading comprehension: A structural equation modeling study. The Modern Language Journal, 96(4), 558-575. https://doi.org/10.1111/j.1540-4781.2012.01398.x

Zimmerman, C. (1996). Historical trends in second language vocabulary instruction. In J. Coady \& T. Huckin (Eds.), Second Language Vocabulary Acquisition: A Rationale for Pedagogy (5-19). Cambridge: Cambridge University Press. doi:10.1017/CBO9781139524643.003 
Appendix A. Sample extracts from reading comprehension test (McGraw, 2009; pp. 69-78)

\section{PRACTICE SET 2}

\section{DESERT FORMATION}

The deserts, which already occupy approximately a fourth of the Earth's land surface, have in recent decades been increasing at an alarming pace. The expansion of desertlike conditions into areas where they did not previously exist is called desertification. It has been estimated that an additional one-fourth of the Earth's land surface is threatened by this process.

Desertification is accomplished primarily through the loss of stabilizing natural vegetation and the subsequent accelerated erosion of the soil by wind and water. In some cases the loose soil is blown completely away, leaving a stony surface. In other cases, the finer particles may be removed, while the sand-sized particles are accumulated to form mobile hills or ridges of sand.

Even in the areas that retain a soil cover, the reduction of vegetation typically results in the loss of the soil's ability to absorb substantial quantities of water. The impact of raindrops on the loose soil tends to transfer fine clay particles into the tiniest soil spaces, sealing them and producing a surface that allows very little water penetration. Water absorption is greatly reduced, consequently run off is increased, resulting in accelerated erosion rates. The gradual drying of the soil caused by its diminished ability to absorb water results in the further loss of vegetation, so that a cycle of progressive surface deterioration is established.

In some regions, the increase in desert areas is occurring largely as the result of a trend toward drier climatic conditions. Continued gradual global warming has produced an increase in aridity for some areas over the past few thousand years. The process may be accelerated in subsequent decades if global warming resulting from air pollution seriously increases.

There is little doubt, however, that desertification in most areas results primarily from human activities rather than natural processes. The semiarid lands bordering the deserts exist in a delicate ecological balance and are limited in their potential to adjust to increased environmental pressures. Expanding populations are subjecting the land to increasing pressures to provide them with food and fuel. In wet periods, the land may be able to respond to these stresses. During the dry periods that are common phenomena along the desert margins, though, the pressure on the land is often far in excess of its diminished capacity, and desertification results.

Four specific activities have been identified as major contributors to the desertification processes: overcultivation, overgrazing, firewood gathering, and overirrigation. The cultivation of crops has expanded into progressively drier regions as population densities have grown. These regions are especially likely to have periods of severe dryness, so that crop failures are common. Since the raising of most crops necessitates the prior removal of the natural vegetation, crop failures leave extensive tracts of land devoid of a plant cover and susceptible to wind and water erosion.

The raising of livestock is a major economic activity in semiarid lands, where grasses are generally the dominant type of natural vegetation. The consequences of an excessive number of livestock grazing in an area are the reduction of the vegetation cover and the trampling and pulverization of the soil. This is usually followed by the drying of the soil and accelerated erosion. 
Firewood is the chief fuel used for cooking and heating in many countries. The increased pressures of expanding populations have led to the removal of woody plants so that many cities and towns are surrounded by large areas completely lacking in trees and shrubs. The increasing use of dried animal waste as a substitute fuel has also hurt the soil because this valuable soil conditioner and source of plant nutrients is no longer being returned to the land.

The final major human cause of desertification is soil salinization resulting from overirrigation. Excess water from irrigation sinks down into the water table. If no drainage system exists, the water table rises, bringing dissolved salts to the surface. The water evaporates and the salts are left behind, creating a white crustal layer that prevents air and water from reaching the underlying soil.

The extreme seriousness of desertification results from the vast areas of land and the tremendous numbers of people affected, as well as from the great difficulty of reversing or even slowing the process. Once the soil has been removed by erosion, only the passage of centuries or millennia will enable new soil to form. In areas where considerable soil still remains, though, a rigorously enforced program of land protection and cover-crop planting may make it possible to reverse the present deterioration of the surface.

The deserts, which already occupy approximately a fourth of the Earth's land surface, have in recent decades been increasing at an alarming pace. The expansion of desertlike conditions into areas where they did not previously exist is called desertification. It has been estimated that an additional one-fourth of the Earth's land surface is threatened by this process.

Directions: Mark your answer by filling in the oval next to your choice.

1. The word threatened in the passage is closest in meaning to

restricted

endangered

prevented

rejected

Even in the areas that retain a soil cover, the reduction of vegetation typically results in the loss of the soil's ability to absorb substantial quantities of water. The impact of raindrops on the loose soil tends to transfer fine clay particles into the tiniest soil spaces, sealing them and producing a surface that allows very little water penetration. Water absorption is greatly reduced, consequently run off is increased, resulting in accelerated erosion rates. The gradual drying of the soil caused by its diminished ability to absorb water results in the further loss of vegetation, so that a cycle of progressive surface deterioration is established.

2. According to paragraph 3 , the loss of natural vegetation has which of the following consequences for soil?

Increased stony content

Reduced water absorption

Increased numbers of spaces in the soil

Reduced water runoff 
Appendix B. Vocabulary size test - Version 2 (Schmitt et al., 2001; pp. 82-87)

\begin{tabular}{|c|c|c|c|}
\hline \multicolumn{4}{|c|}{ The 2000 word level } \\
\hline $\begin{array}{l}1 \text { copy } \\
2 \text { event } \\
3 \text { motor } \\
4 \text { pity } \\
5 \text { profit } \\
6 \text { tip } \\
\end{array}$ & $\begin{array}{l}\text { - end or highest point } \\
\text { - this moves a car } \\
\text { - thing made to be like } \\
\text { another }\end{array}$ & $\begin{array}{l}1 \text { admire } \\
2 \text { complain } \\
3 \text { fix } \\
4 \text { hire } \\
5 \text { introduce } \\
6 \text { stretch } \\
\end{array}$ & $\begin{array}{l}\text { make wider or longer } \\
\text { bring in for the first time } \\
\text { have a high opinion of } \\
\text { someone }\end{array}$ \\
\hline $\begin{array}{l}1 \text { accident } \\
2 \text { debt } \\
3 \text { fortune } \\
4 \text { pride } \\
5 \text { roar } \\
6 \text { thread } \\
\end{array}$ & $\begin{array}{l}\text { loud deep sound } \\
\text { - something you must pay } \\
\text { having a high opinion of } \\
\text { yourself }\end{array}$ & $\begin{array}{l}1 \text { arrange } \\
2 \text { develop } \\
3 \text { lean } \\
4 \text { owe } \\
5 \text { prefer } \\
6 \text { seize } \\
\end{array}$ & $\begin{array}{l}\text { grow } \\
\text { put in order } \\
\text { like more than something } \\
\text { else }\end{array}$ \\
\hline $\begin{array}{l}1 \text { coffee } \\
2 \text { disease } \\
3 \text { justice } \\
4 \text { skirt } \\
5 \text { stage } \\
6 \text { wage }\end{array}$ & $\begin{array}{l}\text { money for work } \\
\text { a piece of clothing } \\
\text { - using the law in the right } \\
\text { way }\end{array}$ & $\begin{array}{l}1 \text { blame } \\
2 \text { elect } \\
3 \text { jump } \\
4 \text { manufacture } \\
5 \text { melt } \\
6 \text { threaten }\end{array}$ & $\begin{array}{l}\text { make } \\
\text { choose by voting } \\
\text { become like water }\end{array}$ \\
\hline $\begin{array}{l}1 \text { clerk } \\
2 \text { frame } \\
3 \text { noise } \\
4 \text { respect } \\
5 \text { theater } \\
6 \text { wine } \\
\end{array}$ & $\begin{array}{l}\text { - a drink } \\
\text { office worker } \\
\text { - unwanted sound }\end{array}$ & $\begin{array}{l}1 \text { ancient } \\
2 \text { curious } \\
3 \text { difficult } \\
4 \text { entire } \\
5 \text { holy } \\
6 \text { social } \\
\end{array}$ & $\begin{array}{l}\text { not easy } \\
\text { very old } \\
\text { related to God }\end{array}$ \\
\hline $\begin{array}{l}1 \text { dozen } \\
2 \text { empire } \\
3 \text { gift } \\
4 \text { opportunity } \\
5 \text { relief } \\
6 \text { tax } \\
\end{array}$ & $\begin{array}{l}\text { chance } \\
\text { twelve } \\
\text { money paid to the } \\
\text { government }\end{array}$ & $\begin{array}{l}1 \text { bitter } \\
2 \text { independent } \\
3 \text { lovely } \\
4 \text { merry } \\
5 \text { popular } \\
6 \text { slight }\end{array}$ & $\begin{array}{l}\text { beautiful } \\
\text { small } \\
\text { liked by many people }\end{array}$ \\
\hline \multicolumn{4}{|c|}{ The 3000 word level } \\
\hline $\begin{array}{l}1 \text { bull } \\
2 \text { champion } \\
3 \text { dignity } \\
4 \text { hell } \\
5 \text { museum } \\
6 \text { solution } \\
\end{array}$ & $\begin{array}{l}\text { formal and serious manner } \\
\text { winner of a sporting event } \\
\text { building where valuable } \\
\text { objects are shown }\end{array}$ & $\begin{array}{l}1 \text { abandon } \\
2 \text { dwell } \\
3 \text { oblige } \\
4 \text { pursue } \\
5 \text { quote } \\
6 \text { resolve } \\
\end{array}$ & $\begin{array}{l}\text { live in a place } \\
\text { follow in order to catch } \\
\text { leave something } \\
\text { permanently }\end{array}$ \\
\hline $\begin{array}{l}1 \text { blanket } \\
2 \text { contest } \\
3 \text { generation } \\
4 \text { merit } \\
5 \text { plot } \\
6 \text { vacation }\end{array}$ & $\begin{array}{l}\text { holiday } \\
\text { good quality } \\
\text { wool covering used on } \\
\text { beds }\end{array}$ & $\begin{array}{l}1 \text { assemble } \\
2 \text { attach } \\
3 \text { peer } \\
4 \text { quit } \\
5 \text { scream } \\
6 \text { toss }\end{array}$ & $\begin{array}{l}\text { look closely } \\
\text { stop doing something } \\
\text { cry out loudly in fear }\end{array}$ \\
\hline $\begin{array}{l}1 \text { comment } \\
2 \text { gown } \\
3 \text { import } \\
4 \text { nerve } \\
5 \text { pasture } \\
6 \text { tradition }\end{array}$ & $\begin{array}{l}\text { long formal dress } \\
\text { goods from a foreign } \\
\text { country } \\
\text { part of the body which } \\
\text { carries feeling }\end{array}$ & $\begin{array}{l}1 \text { drift } \\
2 \text { endure } \\
3 \text { grasp } \\
4 \text { knit } \\
5 \text { register } \\
6 \text { tumble }\end{array}$ & $\begin{array}{l}\text { suffer patiently } \\
\text { join wool threads together } \\
\text { hold firmly with your hands }\end{array}$ \\
\hline $\begin{array}{l}1 \text { administration } \\
2 \text { angel } \\
3 \text { frost } \\
4 \text { herd } \\
5 \text { fort } \\
6 \text { pond } \\
\end{array}$ & $\begin{array}{l}\text { group of animals } \\
\text { spirit who serves God } \\
\text { managing business and } \\
\text { affairs }\end{array}$ & $\begin{array}{l}1 \text { brilliant } \\
2 \text { distinct } \\
3 \text { magic } \\
4 \text { naked } \\
5 \text { slender } \\
6 \text { stable }\end{array}$ & $\begin{array}{l}\text { thin } \\
\text { steady } \\
\text { without clothes }\end{array}$ \\
\hline $\begin{array}{l}1 \text { atmosphere } \\
2 \text { counsel } \\
3 \text { factor } \\
4 \text { hen } \\
5 \text { lawn }\end{array}$ & $\begin{array}{l}\text { _ advice } \\
\text { a place covered with grass } \\
\text { female chicken }\end{array}$ & $\begin{array}{l}1 \text { aware } \\
2 \text { blank } \\
3 \text { desperate } \\
4 \text { normal } \\
5 \text { striking }\end{array}$ & $\begin{array}{l}\text { usual } \\
\text { best or most important } \\
\text { knowing what is happening }\end{array}$ \\
\hline
\end{tabular}




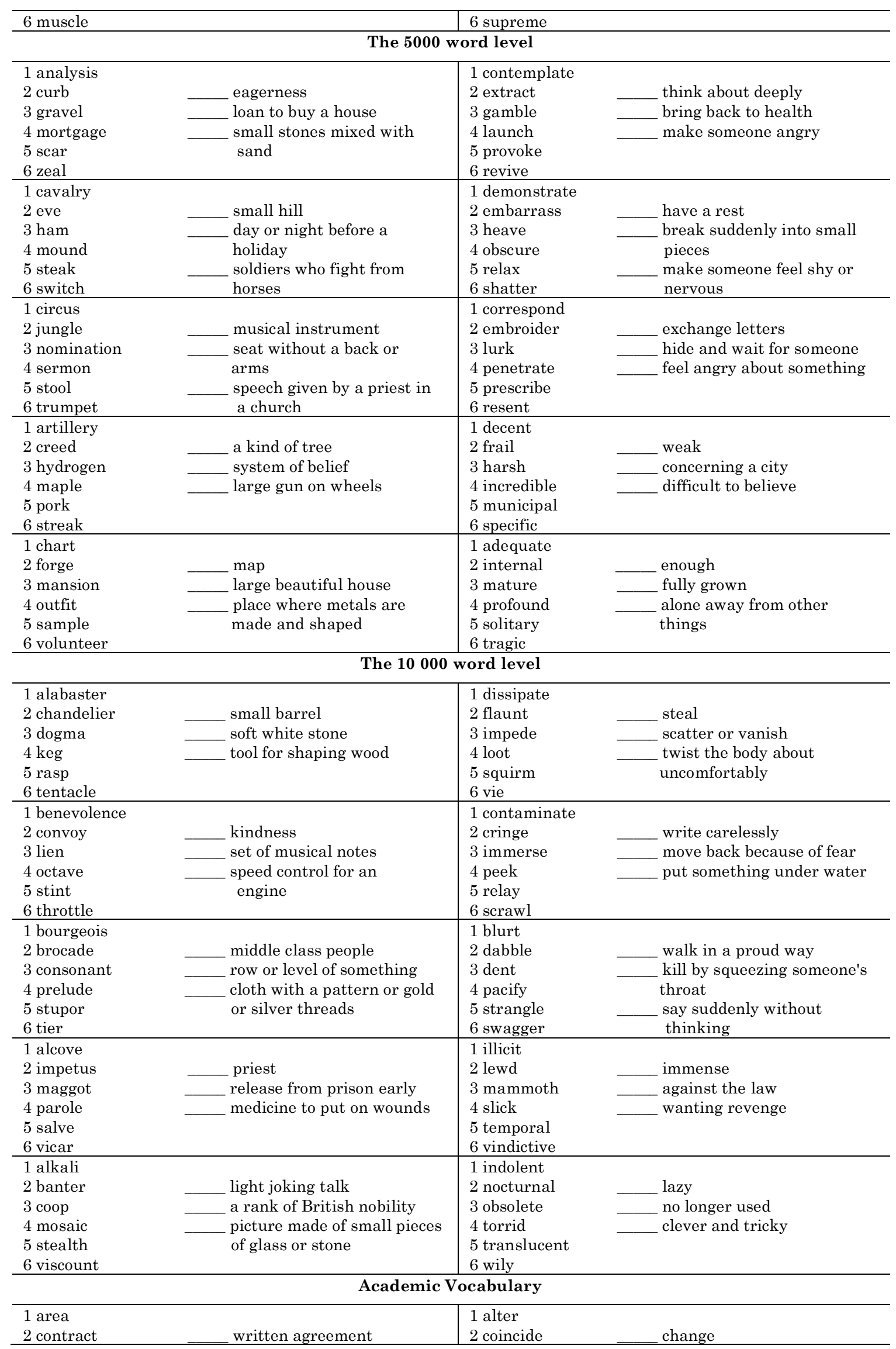




\begin{tabular}{|c|c|c|c|}
\hline $\begin{array}{l}3 \text { definition } \\
4 \text { evidence } \\
5 \text { method } \\
6 \text { role } \\
\end{array}$ & $\begin{array}{l}\text { way of doing something } \\
\text { reason for believing } \\
\text { something is or is not true }\end{array}$ & $\begin{array}{l}\text { deny } \\
4 \text { devote } \\
5 \text { release } \\
6 \text { specify } \\
\end{array}$ & $\begin{array}{l}\text { say something is not true } \\
\text { describe clearly and exactly }\end{array}$ \\
\hline $\begin{array}{l}1 \text { access } \\
2 \text { gender } \\
3 \text { implementation } \\
4 \text { license } \\
5 \text { orientation } \\
6 \text { psychology }\end{array}$ & $\begin{array}{l}\text { male or female } \\
\text { study of the mind } \\
\text { entrance or way in }\end{array}$ & $\begin{array}{l}1 \text { bond } \\
2 \text { channel } \\
3 \text { estimate } \\
4 \text { identify } \\
5 \text { mediate } \\
6 \text { minimize }\end{array}$ & $\begin{array}{l}\text { make smaller } \\
\text { guess the number or size } \\
\text { of something } \\
\text { recognizing and naming } \\
\text { a person or thing }\end{array}$ \\
\hline $\begin{array}{l}1 \text { adult } \\
2 \text { exploitation } \\
3 \text { infrastructure } \\
4 \text { schedule } \\
5 \text { termination } \\
6 \text { vehicle }\end{array}$ & $\begin{array}{l}\text { end } \\
\text { machine used to move } \\
\text { people or goods } \\
\text { list of things to do at } \\
\text { certain times }\end{array}$ & $\begin{array}{l}1 \text { abstract } \\
2 \text { adjacent } \\
3 \text { controversial } \\
4 \text { global } \\
5 \text { neutral } \\
6 \text { supplementary }\end{array}$ & $\begin{array}{l}\text { next to } \\
\text { added to } \\
\text { concerning the whole world }\end{array}$ \\
\hline
\end{tabular}

\section{Copyrights}

Copyright for this article is retained by the author(s), with first publication rights granted to the Journal.

This is an open-access article distributed under the terms and conditions of the Creative Commons Attribution license (CC BY-NC-ND) (http://creativecommons.org/licenses/by-nc-nd/4.0/). 